\title{
IMPLIKASI PEMBERIAN INSENTIF PAJ AK DAN PENGARUHNYA TERHADAP PENINGKATAN INVESTASI DI BIDANG PARIWISATA DI KOTA PADANG
}

\author{
Karlina Sofyarto ${ }^{1}$, Nabitatus Sa'adah² \\ Program Studi Magister Ilmu Hukum \\ Fakultas Hukum Universitas Diponegoro \\ J I. Imam Bardjo, S.H. No. 1-3, Kampus Pleburan, Semarang 50241 \\ karlinasofyarto.003@gmail.com
}

\begin{abstract}
Padang City Government issued Local Regulation No. 11 of 2009 on Providing Incentives and Giving Ease. The regulation functions as a regulation for investors who will invest their capital in Padang City. Approach method used by empirical juridical with research specification is descriptive analytical. The matter studied is how is the legal policy of Padang City Government in encouraging the growth of investment in tourism sector. Second, how is the impact of providing tax incentives on increasing investment in tourism in Padang City. The implementation of One Door Integrated Service (ODIS) in the field of investment supported by Information Service System and Investment Licensing Electronically (ISSILE) is one way to attract investors to invest. These efforts have increased despite not reaching the expected target.
\end{abstract}

Keywords : incentive; invest; tourism

\begin{abstract}
ABSTRAK
Pemerintah Kota Padang mengeluarkan Peraturan Daerah Nomor 11 Tahun 2009 tentang Pemberian Insentif dan Pemberian Kemudahan. Perda tersebut berfungsi sebagai regulasi bagi investor yang akan menanamkan modalnya di Kota Padang. Metode pendekatan yang digunakan yuridis empiris dengan spesifikasi penelitian bersifat deskriptif analitis. Hal yang dikaji yaitu bagaimana kebijakan hukum Pemerintah Kota Padang dalam mendorong peningkatan investasi di bidang pariwisata. Kedua, bagaimana dampak pemberian insentif pajak terhadap peningkatan investasi di bidang pariwisata di Kota Padang. Penerapan Pelayanan Terpadu Satu Pintu (PTSP) di bidang penanaman modal yang didukung dengan Sistem Pelayanan Informasi dan Perizinan Investasi Secara Elektronik (SPIPISE) merupakan salah satu cara menarik investor berinvestasi. Upaya tersebut mengalami peningkatan meskipun belum mencapai target yang diharapkan.
\end{abstract}

Kata Kunci : insentif; investasi; pariwisata

\footnotetext{
1 Mahasiswa Program Studi Magister IImu Hukum Universitas Diponegoro

2 Dosen Program Studi Magister IImu Hukum Universitas Diponegoro
} 


\section{Pendahuluan}

Hubungan Pemerintah Pusat dengan Pemerintah Daerah dapat dilihat dalam alinea ketiga dan keempat Pembukaan Undang-Undang Dasar Negara Republik Indonesia Tahun 1945. Alinea ketiga memuat pernyataan kemerdekaan bangsa Indonesia. Alinea keempat memuat pernyataan bahwa setelah menyatakan kemerdekaan, yang pertama kali dibentuk adalah Pemerintah Negara Indonesia yaitu Pemerintah Nasional yang bertanggung jawab mengatur dan mengurus bangsa indonesia. Lebih lanjut dinyatakan bahwa tugas Pemerintah Negara Indonesia adalah melindungi seluruh bangsa dan tumpah darah Indonesia, memajukan kesejahteraan umum dan mencerdaskan kehidupan bangsa serta ikut memelihara ketertiban dunia berdasarkan kemerdekaan, perdamaian abadi, dan keadilan sosial.

Penanaman modal berperan penting dalam meningkatkan penerimaan pajak, untuk merespon hal tersebut, maka Pemerintah menerbitkan Undang-undang Nomor 25 Tahun 2007 tentang Penanaman Modal. Tujuan Penanaman Modal tertuang didalam ketentuan Pasal 3 ayat (2) Undang-undang Nomor 25 Tahun 2007 tentang Penanaman Modal yaitu :

"untuk meningkatkan pertumbuhan ekonomi nasional, menciptakan lapangan kerja, menigkatkan pembangunan ekonomi berkelanjutan, meningkatkan kemampuan daya saing dunia usaha nasional, meningkatkan kapasitas dan kemapuan teknologi nasional, mendorong pengembangan ekonomi kerakyatan, mengolah ekonomi potensial menjadi kekuatan ekonomi riil dengan menggunakan dana yang berasal, baik dari dalam negeri maupun dari luar negeri, dan meningkatkan kesejahteraan masyarakat."

Indonesia selaku Negara Kesejahteraan (Welfare State) menjadikan pemerintahannya tidak hanya bertanggung jawab terhadap pemeliharaan ketertiban dan keamanan nasional, namun juga pada kesejahteraan ekonomi. Optimalisasi penyelenggaraan penanaman modal menjadi prioritas utama Pemerintah Indonesia sebagai sumber pembiayaan pembangunan, dikarenakan belum mampu mengelola sumber daya manusia, teknologi , keterbatasan dana dan sebagainya. Investasi diharapkan dapat menghasilkan multiplayer effect terhadap pembangunan ekonomi nasional, karena kegiatan investasi tidak saja mentransfer modal dan barang, tetapi juga mentransfer ilmu pengetahuan dan sumber daya manusia. (Dellisa A. Ridgway dan Mariya A. Thalib, 2003)

Memperhatikan hal tersebut, maka urgensi penanaman modal bagi Indonesia didasarkan pada beberapa hal yaitu subtitusi impor ekonomi modern yang diharapkan mampu mengantarkan ekonomi Indonesia kearah industrialis, pembangunan infrastruktur dae4ah tertinggal, alih 
teknologi dan stimulus sektor riil perekonomian nasional.

Penarikan arus investasi kedalam suatu negara sangat dipengaruji oleh iklim investasi yang kondusif dan prospek pengembangan di daerah negara tersebut. (Handayani, 2011) Permasalahan yang menjadi hambatan dalam peningkatan investasi di tingkat pusat maupun daerah antara lain banyak peraturan yang menghambat datangnya penanam modal, regulasi peraturan yang berlebihan, kualitas konsistensi regulasi perpajakan yang tidak memberikan ruang lebih kepada pengusaha yang berdampak penanam modal memilih untuk berinvestasi di daerah lain yang memberikan kemudahan perpajakan, kualitas SDM yang relatif masih rendah, masalah pertanahan di pemerintah pusat dan pemerintah daerah.

Penanam modal yang tertarik untuk berinvestasi terkendala masalah sertifikasi, izin bangunan serta zonasi lahan, serta masalah infrastruktur sebagai pendukung utama dari industri. Apabila Pemerintahan Pusat maupun Pemerintahan Daerah melakukan konsolidasi dan koordinasi secara intensif dan berkesinambungan maka permasalahan-permasalahan yang telah disebutkan sebelumnya dapat diatasi dengan mudah serta mampu menciptakan tindakan preventif apabila di masa yang akan datang terdapat masalah yang sama sehingga penerimaan keuangan negara pada sektor pajak yang di ambil dari sisi penanaman modal dapat terselenggara dengan baik.

Berdasarkan tinjauan dari aspek insentif pajak dan daya saing investasi, pajak merupakan salah satu kebijakan yang memberi pengaruh terhadap peningkatan investasi. Hal tersebut diharapkan dapat menurunkan biaya produksi, biaya modal dan meningkatkan daya saing. Ditinjau dari segi penerimaan daerah, eranan pajak sangatlah vital bagi keberlangsungan perekonomian suatu daerah sebagai pendukung kegiatan rumah tangga daerah didasarkan suatu peraturan perundangundangan. Pembayaran pajak akan meningkat jika investasi berjalan baik, industri berkembang, menyerap tenaga kerja, daya beli rakyat meningkat.

Kebijakan insentif pajak di Kota Padang diatur dalam Peraturan Daerah Kota Padang Nomor 11 Tahun 2009 tentang Pemberian Insentif Dan Kemudahan Penanaman Modal. Perda tersebut digunakan untuk mendukung terciptanya iklim investasi di bidang pariwisata di Kota Padang yang memberikan pengaruh terhadap peningkatan penerimaan daerah Kota Padang. Memperhatikan kedua aspek tersebut, investor mengharapkan paket kebijakan pendukung investasi seperti deregulasi perizinan, keringanan pajak dan kepabeanan, suku bunga dan lain-lain.

Kota Padang memiliki berbagai macam budaya dan ciri khas tersendiri di setiap daerahnya. Hal inilah yang menjadikan Kota 
Padang memiliki cukup banyak kawasan obyek wisata yang berpotensi menghasilkan pajak daerah dan retribusi daerah yang cukup besar yang bersumber dari sektor pariwisata. Dalam menunjang percepatan pembangunan sektor pariwisata Kota Padang, maka Pemerintah Daerah diharapkan mampu menyelenggarakan sistem pelayanan publik yang baik dan kemudahan perizinan dalam berusaha yang diharapkan mampu menciptakan lapangan kerja baru dan memperbaiki tingkat pendapatan masyarakat.

Berdasarkan latar belakang tersebut, maka rumusan masalahnya sebagai berikut : pertama bagaimana kebijakan hukum Pemerintah Kota Padang dalam mendorong peningkatan investasi di bidang pariwisata. Kedua, bagaimana dampak pemberian insentif pajak terhadap peningkatan investasi di bidang pariwisata di Kota Padang.

\section{Metode Penelitian}

Metode pendekatan yang digunakan dalam penelitian ini adalah yuridis empiris. Yuridis empiris yaitu suatu penelitian yang menekankan pada data primer yang diperoleh langsung dari lapangan berupa hasil wawancara dari narasumber (Soekanto, 1982). Spesifikasii penelitian yang digunakan dalam penelitian ini bersifat deskriptif analitis. Deskriptif analitis dalam penelitian ini bertujuan untuk memberikan gambaran secara rinci, sistematis dan menyeluruh mengenai segala sesuatu yang berhubungan dengan masalah yang diteliti, yaitu pemberian insentif pajak dalam kemudahan penanaman modal dibidang pariwisata dikaitkan dengan teori-teori hukum dan praktek pelaksanaan hukum positif yang menyangkut permasalahan diatas.

\section{Pembahasan}

\section{Kebijakan Hukum Pemerintah Kota Padang Dalam Mendukung Investasi Di Bidang Pariwisata}

Hakikat pemberian otonomi daerah bertujuan untuk memberikan kemandirian pada Daerah untuk meningkatkan kesejahteraan masyarakat melalui peningkatan hak dan kewajiban pemerintah Daerah untuk mengatur urusan rumah tangga Pemerintahan daerahnya sendiri. (Kurniawan, 2013) Wujud pelimpahan kewenangan dan kewajiban kepada Pemerintah daerah dari Pemerintah Pusat adalah adanya kewenangan Pemerintahan dalam menyusun produk hukum untuk melaksanakan program pembangunan.

Pelaksanaan otonomi daerah diharapkan oleh Pemerintah Pusat sebagai suatu peluang kepada daerah untuk menyusun konsep pembangunan keberlanjutan sesuai dengan karakteristik masyarakat dan potensi sumber daya daerah masing-masing. Sehubungan dengan penyelenggaraan otonomi daerah, penanaman moda; menjadi faktor potensial dalam membangun pertumbuhan perekonomian lokal. 
Peranan Pemerintah Daerah menjadi lebih untuk membuat suatu regulasi hukum dalam penting dan strategis dalam merumuskan setiap rangka meningkatkan penanaman modal di kebijakan pembngunan perekonomian lokal daerah. Peraturan Presiden Nomor 91 Tahun sejalan dengan semangat desentralisasi. 2017 tentang Percepatan Pelaksanaan Berusaha (Bintang, 2010). Dalam rangka mendorong menyebutkan bahwa DPMPTSP Provinsi atau peningkatan daya saing penanaman modal, DPMPTSP kabupaten/kota berperan penting Pemerintah Daerah Kota Padang mengeluarkan Peraturan Daerah Kota Padang No 11 Tahun 2009 tentang Pemberian Insentif dan Pemberian Kemudahan Penanaman Modal guna dalam melaksanakan percepatan Perizinan Berusaha di kawasan industri dan kawasan strategis pariwisata nasional dalam bentuk pemenuhan persyaratan.

meningkatkan Anggaran Pendapatan dan Belanja Pemberian insentif berdasarkan Peraturan Daerahnya. Pemberian insentif merupakan dukungan dari pemerintah daerah kepada penanam modal dalam rangka mendorong peningkatan penanaman modal di daerah. Pemberian insentif berbentuk pengurangan, keringanan atau pajak daerah dan retribusi daerah.

Ketentuan Pasal 278 Undang-undang Nomor 23 Tahun 2014 tentang Pemerintah Daerah merupakan landasan hukum bagi pemerintah daerah untuk memberikan insentif dan kemudahan dibidang penanaman modal. Bentuk upaya pelaksanaan koordinasi antara pemerintah pusat dengan pemerintah daerah terhadap pemberian fasilitas yang diberikan terkait penanam modal, pemerintah telah mengeluarkan Peraturan Pemerintah Nomor 45 Tahun 2008 tentang Pedoman Pemberian Insentif dan Pemberian Kemudahan Penanaman Modal di daerah, sebagai dasar pelaksanaannya di daerah

Pemerintah Nomor 45 Tahun 2008 dapat berbentuk pengurangan, keringanan atau pembebasan pajak daerah dan retribusi daerah, pemberian dana stimulan, dan pemberian bantuan modal. Pemberian kemudahan dapat berbentuk penyediaan data dan informasi peluang penanaman modal, penyediaan sarana dan prasarana, penyediaan lahan atau lokasi, pemberian bantuan teknis, dan percepatan pemberian perizinan. Pemberian kemudahan penanaman modal dalam bentuk percepatan pemberian perizinan dilaksanakan melalui Dinas Penanaman Modal dan Pelayanan Terpadu Satu Pintu (DPMPTSP).

\section{Berdasarkan Peraturan Daerah Kota}

Padang Nomor 11 Tahun 2009 pemberian insentif dapat berbentuk pengurangan, keringanan atau pembebasan pajak daerah dan retribusi daerah. Pemberian kemudahan yang lain yaitu fasilitas penyediaan sarana dan prasarana, pemberian 
bantuan teknis, fasilitas penyediaan lahan atau lokasi, penyediaan data dan informasi peluang penanaman modal dan percepatan pemberian izin. Jenis usaha kegiatan penanaman modal yang diprioritaskan memperoleh insentif dan kemudahan yaitu jenis usaha di bidang perdagangan, pariwisata dan pendidikan.

DPMPTSP Provinsi Kota Padang memberikan kemudahan dan keunggulan kepada investor yang akan menanamkan modalnya di Kota Padang dengan nilai nominal tertentu, dan dengan menyerap tenaga kerja tertentu akan diberikan insentif berupa pengurangan pembayaran pajak dan retribusi terkait usaha yang bersangkutan selama dua tahun. Pajak dan retribusi dimaksud adalah yang merupakan kewenangan Pemerintah kota Padang, seperti IMB, pajak parkir, retribusi izin gangguan, pajak reklame dan lainnya. Kota Padang sebagai Kota Potensial investasi mendapatkan penghargaan dari Indonesia Attractiveness Award (IAA) tahun 2016 sebagai kota potensial investasi untuk koridor Sumatera.

Kepala Bidang Promosi dan pengawasan Penanaman Modal DPMPTSP mengatakan bahwa untuk mendorong masuknya investasi di Kota Padang dengan memberikan sejumlah kemudahan, termasuk kepastian soal kemudahan mendapatkan lahan dan keamanan berinvestasi. Kemudahan lainnya berupa pengurusan izin, ketegasan waktu penyiapan dokumen dan pemberian insentif di sektor pajak serta retribusi Menurut teori bekerjanya hukum Chambliss Seidman, hukum akan dapat bekerja dengan baik dan efektif dalam masyarakat yang diaturnya. Dalam teori bekerjanya hukum terdapat empat unsur yang berkaitan sangat erat, yaitu (Hazjimsun, 2014) : Pertama, setiap Peraturan hukum menunjukan bagaimana cara para pemegang peran harus bertindak. DPRD Kota Padang memegang kekuasaan membentuk peraturan daerah tentang pemberian insentif dan kemudahan penanaman modal dan walikota berkewajiban mengesahkan peraturan daerah tersebut. Pada tahap pembuatan kebijakan publik, kekuatan sosial dan personal baik yang berasal dari masyarakat ataupun pihak swasta memberikan pengaruh yang cukup besar terhadap institusi atau lembaga pembuat kebiajakn publik.

Kedua, bagaimana pemegang peranan itu akan bertindak sebagai respons terhadap peraturan hukum menurut fungsi peraturan hukum yang ditujukan pada sanksi-sanksinya, aktivitas lembaga-lembaga pelaksana serta kesuluruhan kompleks sosial politik dan lain-lain. Walikota sebagai institusi pemegang peran akan bertindak suatu respon terhadap peraturan daerah yang telah ditetapkan.

Ketiga, bagaimana lembaga itu bertindak dalam merespons terhadap peraturan hukum 
serta umpan balik yang datang dari pemegang peran. Masyarakat dan swasta mempunyai peranan sebagai obyek diberlakukannya suatu kebijakan publik. Pengertian masyarakat dalam konteks ini tidak hanya mencakup civil society tetapi juga mencakup sektor swasta yang berkepentingan memanfaatkan sarana yang dibebani oleh pajak daerah untuk mendapatkan keuntungan. Masyarakat memiliki kesempatan untuk berperan serta dalam penyelenggaraan penanaman modal dengan cara penyampaian saran dan penyampaian informasi potensi daerah yang bertujuan untuk mewujudkan penanaman modal yang berkelanjutan

Keempat, Bagaimana para pembuat peraturan perundang-undangan ini akan bertindak dalam menjalankan fungsi peraturan-peraturan yang mengatur tingkah laku mereka, keseluruhan sanksi-sanksi, kompleksitas kekuatan sosial politik, ideologi dan lain-lain serta umpan balik dari Birokrasi, keempat unsur ini dapat diketahui masyarakat sebagai pemegang peranan yang dtingkah lakunya ditentukan oleh pola peranan yang diterapkan pada norma-norma hukum maupun faktor-faktor non hukum. Peraturan dan norma yang telah dibuat dan diberlakukan dimasyarakat akan direspon dalam bentuk tindakan oleh masyarakat berupa kepatuhan atau ketidakpatuhan sebagai umpan balik dair penerapan kebijakan tersebut. Kekuatan struktural ini mutlak diperlukan untuk melakukan pembiayaan pemerintahan dalam penyelenggaraan pembangunan. 


\section{Bagan 1 : Alur Bekerjanya Hukum Dalam Pemberian Insentif Perpajakan di Kota Padang}

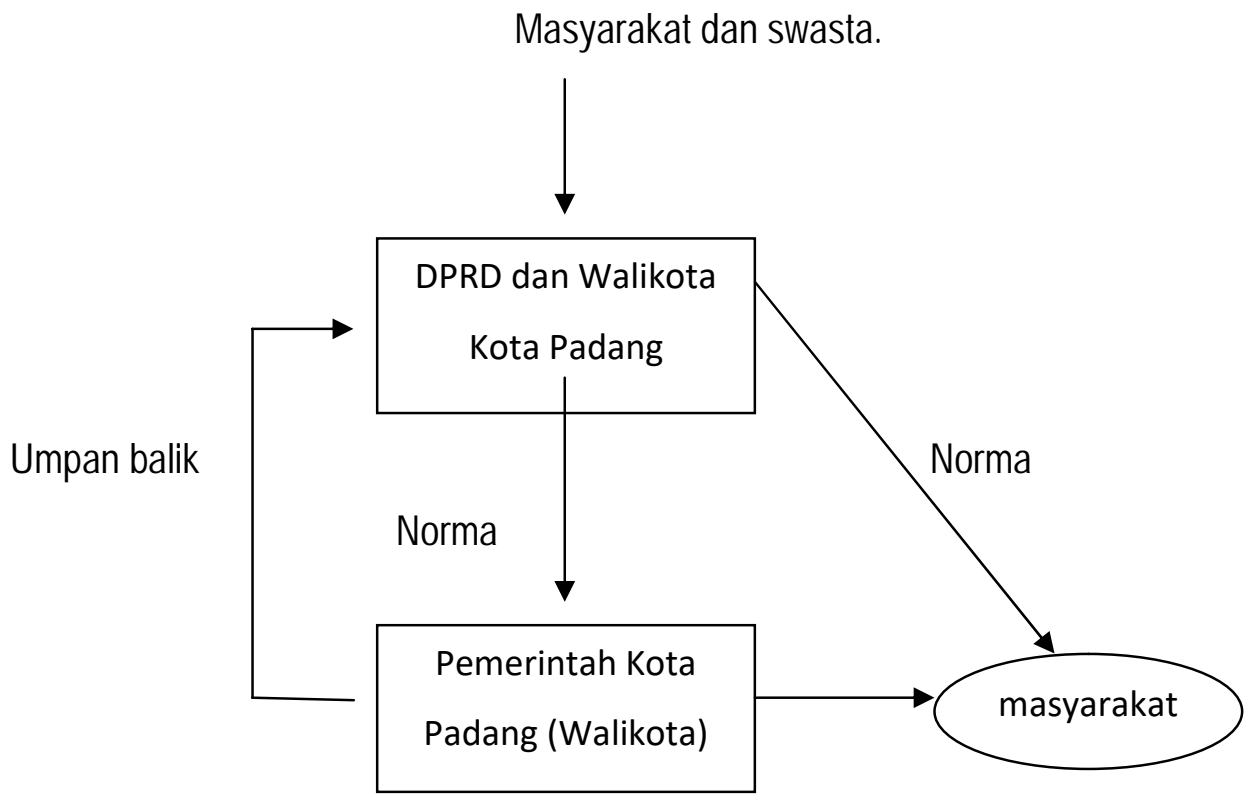

Peraturan Daerah Kota Padang No 11 Tahun 2009 tentang Pemberian Insentif dan Pemberian Kemudahan Penanaman Modal sebagai produk hukum dapat dikatakan efektif, jika peraturan tersebut dilaksanakan, diataati dan mampun menjadi alat rekayasa sosial sesui tujuan dikeluarkannya aturan tersebut.

Menurut Lawrence Friedman terdapat tiga faktor yang mempengaruhi keberhasilan upaya pengakan hukum yaitu (Juwana, 2012) :

1). Produk hukum berupa peraturan dan ketentuan yang berlaku

law).

2). Infrastruktur pendukung berupa penegak hukum (Legal Structure).
3). Budaya hukum yang berkembang dalam masyarakat (Legal Cuture).

Lahirnya kebijakan tentang pemberian insentif dan kemudahan penanaman modal ini diharapkan mampu menarik investor asing maupun domestik untuk mau berinvestasi di Kota Padang, khususnya investasi dibidang pariwisata. Sektor pariwisata merupakan salah satu potensi yang memiliki muatan ekonomi kerakyatan yang perlu dikembangkan dalam rangka kesejahteraan masyarakat dan pembangunan khususnya di daerah-daerah secara menyeluruh dan merata. Hal ini diperlukan adanya pembinaan yang lebih terarah dan terkoordinir oleh pihak-pihak yang terkait dnegan pengembangan bidang pariwisata secara lokal maupun regional. Secara sederhana dapat diungkapkan bahwa pariwisata menjadi 
suatu bagian yang penting dan bagian yang teritegrasi dalam strategi pembangunan ekonomi suatu daerah.

\section{Dampak Pemberian Insentif Pajak Terhadap} Investor Dalam Percepatan Pembangunan Di Bidang Pariwisata Di Kota Padang

Pasal 278 Undang-undang Nomor 23 Tahun 2014 tentang Pemerintah Daerah, Pasal 7 Peraturan Pemerintah Nomor 45 Tahun 2008 tentang Pedoman Pemberian Insentif dan Pemberian Kemudahan Penanaman Modal Di Daerah, dan Peraturan Presiden Nomor 91 Tahun 2017 tentang Percepatan Pelaksanaan berusaha merupakan dasar hukum dan buah pemikiran Kota Padang dalam merealisasikan Percepatan Pembangunan khususnya di Bidang pariwisata. Selanjutnya terkait dengan aturan hukum tersebut, Pemerintah Kota Padang merumuskan serta mengesahkan Peraturan Daerah Kota Padang Nomor 11 Tahun 2009 tentang Pemberian Intensif dan Pemberian Kemudahan Penanaman Modal yang di tandatangani oleh Bapak Fauzi Bahar selaku Walikota Padang pada tanggal 27 Juli 2009, hal tersebut merupakan salah satu langkah Pemerintah Kota Padang dalam rangka mengimplementasikan serta menjalankan perintah undang-undang serta meningkatkan upaya agar para investor lebih tertarik untuk menanamkan modalnya di Kota Padang. Faktor penunjang terkait hal tersebut antara lain dengan perlunya diberikan insentif dan kemudahan penanaman modal. Kegiatan penanaman modal yang diprioritaskan memperoleh insentif dan kemudahan adalah jenis usaha atau kegiatan dibidang perdagangan, pariwisata dan pendidikan yang termasuk dalam lingkup bidang usaha yang terbuka.

Secara umum penanaman modal baik dalam bentuk Penanaman Modal Dalam Negeri (PMDN) maupun Penanaman Modal Asing (PMA) membutuhkan iklim investasi yang kondusif dan proses pelayanan publik yang berkualitas. Dengan kondisi iklim investasi yang kondusif diharapkan banyak perusahaan dapat meningkatkan aktivitasnya, para pekerja dan perusahaan yang berkaitan akan meningkat daya belinya yang pada akhirmya meningkatkan penerimaan pajak. Selain itu, pemerintah daerah juga wajib menekankan kepada investor mengenai konsep pengelolaan investasi sektor pariwisata yang berkelanjutan (suistainable), bukan industri hasil keuntungan sesaat. Hal ini dilakukan untuk mewujudkan Kota Padang sebagai kota pendidikan, perdagangan dan pariwisata yang sejahtera, religius dan berbudaya. 
Jurnal Law Reform

Volume 14, Nomor 1, Tahun 2018
Program Studi Magister Ilmu Hukum

Fakultas Hukum Universitas Diponegoro

Tabel 1.1

Rincian Insentif Penanaman Modal

\begin{tabular}{|c|c|c|c|c|c|c|}
\hline No & $\begin{array}{l}\text { Insentif Pajak (Dua Tahun Pertama) } \\
\text { dan Retribusi Daerah }\end{array}$ & Kelas A & Kelas B & Kelas C & Kelas D & Kelas E \\
\hline 1 & Pajak Parkir & $100 \%$ & $80 \%$ & $60 \%$ & $40 \%$ & $20 \%$ \\
\hline 2 & Pajak Hotel & $100 \%$ & $80 \%$ & $60 \%$ & $40 \%$ & $20 \%$ \\
\hline 3 & Pajak Restoran & $100 \%$ & $80 \%$ & $60 \%$ & $40 \%$ & $20 \%$ \\
\hline 4 & Pajak Hiburan & $100 \%$ & $80 \%$ & $60 \%$ & $40 \%$ & $20 \%$ \\
\hline 5 & Pajak Reklame & $100 \%$ & $80 \%$ & $60 \%$ & $40 \%$ & $20 \%$ \\
\hline 6 & Retribusi Rencana Kota & $100 \%$ & $80 \%$ & $60 \%$ & $40 \%$ & $20 \%$ \\
\hline 7 & Retribusi izin pemanfaatan bangunan & $100 \%$ & $80 \%$ & $60 \%$ & $40 \%$ & $20 \%$ \\
\hline 8 & Retribusi izin mendirikan bangunan & $100 \%$ & $80 \%$ & $60 \%$ & $40 \%$ & $20 \%$ \\
\hline 9 & Retribusi izin gangguan & $100 \%$ & $80 \%$ & $60 \%$ & $40 \%$ & $20 \%$ \\
\hline 10 & Retribusi pemakaian kekayaan daerah & $100 \%$ & $80 \%$ & $60 \%$ & $40 \%$ & $20 \%$ \\
\hline 11 & Retribusi pelayanan persampahan & $100 \%$ & $80 \%$ & $60 \%$ & $40 \%$ & $20 \%$ \\
\hline 12 & Retribusi izin usaha perikanan & $100 \%$ & $80 \%$ & $60 \%$ & $40 \%$ & $20 \%$ \\
\hline & Retribusi pengujian kapal perikanan & $100 \%$ & $80 \%$ & $60 \%$ & $40 \%$ & $20 \%$ \\
\hline 14 & $\begin{array}{l}\text { Retribusi pemeriksaan alat pemadam } \\
\text { kebakaran }\end{array}$ & $100 \%$ & $80 \%$ & $60 \%$ & $40 \%$ & $20 \%$ \\
\hline 15 & Retribusi Rumah potong hewan & $100 \%$ & $80 \%$ & $60 \%$ & $40 \%$ & $20 \%$ \\
\hline 16 & Retribusi izin usaha perfilman & $100 \%$ & $80 \%$ & $60 \%$ & $40 \%$ & $20 \%$ \\
\hline 17 & $\begin{array}{l}\text { Retribusi izin usaha industri dan } \\
\text { perdagangan }\end{array}$ & $100 \%$ & $80 \%$ & $60 \%$ & $40 \%$ & $20 \%$ \\
\hline 18 & Retribusi izin usaha pariwisata & $100 \%$ & $80 \%$ & $60 \%$ & $40 \%$ & $20 \%$ \\
\hline 19 & $\begin{array}{l}\text { Retribusi pengujian } \\
\text { Kendaraan bermotor }\end{array}$ & $100 \%$ & $80 \%$ & $60 \%$ & $40 \%$ & $20 \%$ \\
\hline 20 & Retribusi pelayanan pelabuhan kapal & $100 \%$ & $80 \%$ & $60 \%$ & $40 \%$ & $20 \%$ \\
\hline 21 & $\begin{array}{l}\text { Retribusi wajib daftar perusahaan dan } \\
\text { pendaftaran gudang }\end{array}$ & $100 \%$ & $80 \%$ & $60 \%$ & $40 \%$ & $20 \%$ \\
\hline
\end{tabular}

Sumber : BPMPTSP Kota Padang 
Peraturan Daerah Kota Padang Nomor 11 Tahun 2009, tabel tersebut menjelaskan bahwa Kelas $A$ dengan nilai investasi Rp 1.000.000.000.000,- (satu triliun rupiah) atau lebih dan menyerap tenaga kerja lokal lebih dari 500 (lima ratus) orang, maka diberikan insentif dan kemudahan potongan biaya 100\% (seratus persen) atau tanpa biaya (zero cost) untuk dua tahun pertama terhitung semenjak diterbitkannya keputusan tentang pemberian insentif oleh Walikota.

Kelas B dengan nilai investasi lebih dari Rp 500.000.000.000,- (lima ratus milyar rupiah) sampai kurang dari Rp 1.000.000.000.000 (satu triliun rupiah) atau menyerap tenaga kerja lokal lebih dari 250 (dua ratus lima puluh) orang sampai dengan 500 (lima ratus) orang, maka diberikan insentif dan kemudahan potongan biaya $80 \%$ (delapan puluh persen) untuk dua tahun pertama.

Kelas $\mathrm{C}$ dengan nilai investasi lebih dari $\mathrm{Rp}$ 100.000.000.000,- (seratus milyar rupiah) sampai dengan Rp 500.000.000.000,- (lima ratus milyar rupiah) atau menyerap tenaga kerja lokal 100 (seratus) orang sampai dengan 250 (dua ratus lima puluh) orang, maka diberikan insentif dan kemudahan potongan biaya 60\% (enam puluh persen) untuk dua tahun pertama.

Kelas D dengan nilai investasi lebih dari Rp 50.000.000.000,- (lima puluh milyar rupiah) sampai dengan Rp 100.000.000.000,- (seratus milyar rupiah) atau menyerap tenaga kerja lokal lebih dari 50 (lima puluh) orang sampai dengan 100 (seratus) orang, maka diberikan insentif dan kemudahan potongan biaya 40\% (empat puluh persen) untuk dua tahun pertama.

Kelas $\mathrm{E}$ dengan nilai investasi $\mathrm{Rp}$ 1.000.000.000,- (satu milyar rupiah) sampai dengan Rp 50.000.000.000,- (lima puluh milyar rupiah) atau menyerap tenaga kerja lokal 10 (sepuluh) orang sampai dengan 50 (lima puluh) orang, maka diberikan insentif dan kemudahan potongan biaya 20\% (dua puluh persen) untuk dua tahun pertama terhitung semenjak diterbitkannya keputusan tentang pemberian kemudahan oleh Walikota.

Adam Smith dalam bukunya An Inquiry Into The Nature and Causes of The Wealth of Nation menyebutkan empat asas dalam pemungutan pajak yang dikenal dengan four maxims, salah satunya asas equity (keadilan). Prinsip keadilan merupakan suatu prinsip yang menjadi pertimbangan utama dalam pembuatan kebijakan negara. Adil dimaksudkan bahwa setiap wajib pajak menyumbangkan uang untuk pengeluaran pemerintah sebanding dengan kepentingan dan manfaat. Teori keadilan disini berlaku bagi perusahan PMDN dan PMA yang menanamkan modalnya sesuai dengan persyaratan yang telah ditetapkan oleh Peraturan Pemerintah Daerah Kota Padang akan diberikan pemberian insentif dan pemberian kemudahan dengan nilai investasi dan jumlah tenaga kerja lokal yang diserap. 
Dalam keadaan yang sama, para wajib pajak harus dikenakan pajak yang sama pula.

Menurut teori yang dikemukakan Adam Smith bahwa terdapat dua aspek utama pertumbuhan ekonomi yaitu pertumbuhan output total yang terdiri dari sumber daya alam, sumber daya manusia dan pertumbuhan penduduk yang mempunyai peranan penting dalam pertumbuhan ekonomi (Supartoyo, Tatuh, \& Sendouw, 2013).

Berdasarkan sudut pandang ekonomi, bahwa lahirnya kebijakan daerah Kota Padang yang mengatur tentang pemberian insentif dan pemberian kemudahan penanaman modal untuk meningkatkan pendapatan asli daerah Kota Padang. Fungsi utama dari pemungutan pajak adalah budgetair, artinya sebagai sumber pembiayaan daerah atau sumber keuangan daerah, maka diperlukan untuk mengakomodasi potensi keuangan daerah dengan memajukan bidang pariwisata.

Teori kemanfaatan menurut ajaran Adam Smith yaitu berdasarkan kriteria sistem perpajakan yang adil. Salah satu tujuan kegiatan pemerintah dan masyarakat adalah menciptakan manfaat dapat dinikmati oleh seluruh warga Negara, baik sebagai konsumen maupun produsen. Apabila manfaat yang diterima masyarakat/warga negara dirasakan besar, maka warga Negara akan bersedia membayar manfaat tersebut juga dalam jumlah yang besar. Pariwisata merupakan salah satu sumber PAD
Kota Padang yang memberikan efek berantai (multiplier effect) dalam hal kemampuannya untuk memunculkan usaha-usaha lain sebagai sumber pendapatan masyarakat.

Berdasarkan hasil wawancara dengan Bapak Richardi sebagai Kabid Promosi dan Pengawasan Penanaman Modal DPMPTSP Kota Padang, tingkat investasi pada sektor pariwisata masih rendah. Sumber Investasi terbesar berasal dari sektor perdagangan dan jasa. Salah satu penyebabnya adalah para investor masih mencari peluang pengembangan bisnis pariwisata di Kota Padang Meskipun DPMPTSP Kota Padang telah melakukan sejumlah terobosan, agar investor semakin tertarik menanamkan modalnya seperti adanya insentif kepada investor sesuai nilai investasinya. DPMPTSP sudah berupaya menarik investor untuk berinvestasi di sektor pariwisata. Sebagian besar investor baru tertarik berinvestasi di sektor pendukung pariwisata seperti hotel. Faktor lain disebabkan karena belum jelasnya aturan terkait pengelolaan pulau-pulau wisata. DPMPTSP dalam waktu dekat bersama DPD dan pihak terkait akan menyelesaikan permasalahan tersebut sehingga sehubungan dengan hal tersebut sebagian besar para investor manjadi lebih tertarik untuk berinvestasi dibidang pariwisata. Mengingat belum tercapainya target investasi pariwisata tahun 2017 yaitu 50\% (lima puluh persen) dari Rp 1.100.000.000.000,- (satu triliun seratus milyar rupiah) yang terelalisasi 
Jurnal Law Reform

Volume 14, Nomor 1, Tahun 2018
Program Studi Magister Ilmu Hukum

Fakultas Hukum Universitas Diponegoro hanya Rp 480.000.000.000 (empat ratus delapan puluh milyar rupiah) dibidang pariwisata hingga akhir tahun 2017 disebabkan perlambatan ekonomi nasional yang ikut mempengaruhi minat investasi di Kota Padang.

Ketergantungan Pemerintah Daerah Kota Padang akan dana perimbangan dari pemerintah pusat sangat besar dan menyebabkan kemandirian Pemerintah Daerah Kota Padang sangat lemah. Hal ini terjadi karena Pendapatan Asli Daerah Kota Padang belum mampu menjadi penopang pembiayaan pembangunan. Untuk itu sangat diperlukan penggalian potensi pajak dan retribusi daerah, dan meningkatkan iklim investasi yang kondusif dalam rangka menarik minat investor untuk menanamkan modal di Kota Padang. Pada kenyataannya belum banyak investor yang mau berinvestasi di Kota Padang, salah satunya disebabkan oleh kepastian lahan yang menjadi isu bagi investor untuk menanamkan modalnya, dan Kota Padang termasuk kedalam daftar daerah rawan bencana. Kepastian lahan dalam pengembangan kawasan wisata terpadu Gunung Padang mencakup luas 400 hektar dengan status kepemilikan lahan adalah tanah negara dan tanah ulayat milik masyarakat setempat. Untuk mengatasi masalah masalah tersebut, pemerintah Kota Padang perlu menyiapkan instrumen regulasi untuk proteksi destinasi. Mengenai tanah ulayat yang digunakan dalam penanaman modal diatur oleh Peraturan
Daerah Kota Padang Nomor 3 Tahun 2012 tentang Penanaman Modal dimana kebijakan dasar penanaman modal yang menggunakan tanah ulayat dilakukan dengan prinsip saling menguntungkan dan berbagi risiko melalui musyawarah untuk mufakat.

\section{Simpulan dan Saran}

\section{a. Simpulan}

Kebijakan hukum pemerintah Kota Padang dalam mendukung investasi dibidang pariwisata yaitu mengeluarkan Peraturan Daerah Kota Padang No 11 Tahun 2009 tentang Pemberian Insentif dan Pemberian Kemudahan Penanaman Modal. Pemberian insentif berbentuk pengurangan, keringanan atau pembebasan pajak daerah dan retribusi daerah. Pemberian kemudahan berbentuk fasilitas penyediaan sarana dan prasarana, pemberian bantuan teknis, fasilitas penyediaan lahan atau lokasi, penyediaan data dan informasi peluang penanaman modal dan atau percepatan pemberian izin. Pengaruh pemberian insentif pajak terhadap investor dalam percepatan pembangunan di bidang Pariwisata Di Kota Padang yaitu mengalami peningkatan meskipun belum mencapai target yang diharapkan, disebabkan Pemerintah Kota Padang dinilai masih belum maksimal dalam menggarap potensi pariwisata untuk meningkatkan PAD. Hal tersebut disebabkan kepastian lahan yang menjadi isu bagi investor untuk menanamkan 
Jurnal Law Reform

Volume 14, Nomor 1, Tahun 2018

modalnya, dan belum jelasnya aturan terkait pengelolaan pulau-pulau wisata.

\section{b. Saran}

Pemerintah Kota Padang perlu melakukan evaluasi dan kajian secara komprehensif terhadap pengembangan kawasan obyek wisata yang dapat memberikan stimulus bagi investasi $d i$ sektor pariwisata Kota Padang. Salah satu langkah yang dilakukan oleh Pemerintah Kota Padang yaitu melakukan koordinasi dengan masyarakat daerah setempat untuk menggali informasi potensi pariwisata, serta melibatkan masyarakat untuk berpartisipasi secara dalam mengelola daerah kawasan wisata.

\section{Daftar Pustaka}

Badan Pembinaan Hukum Nasional (BPHN). (2011). Kompendium Bidang Hukum Investasi, Di Bawah Pimpinan I.B.R. Supancana, Editor Tana Mantiri, Kementrian Hukum dan HAM. Jakarta : BPHN.

Manan, B. (2005). Menyongsong Fajar Otonomi Daerah. Yogyakarta : Pusat Studi Hukum Fakultas Hukum Universitas Islam Indonesia.

Soemitro, R. (1998). Pajak Ditinjau Dari Segi Hukum. Bandung : Rosda Offset.

Sa'adah, N. (2009). Membentuk Model Upaya Hukum Pajak Yang Sesuai Dengan Prinsip Equality (Kesamaan)Dan Equity (keadilan),
Program Studi Magister Ilmu Hukum Fakultas Hukum Universitas Diponegoro

Retrieved From http://eprints.undip.ac.id /7516/1/nabitatus.pdf, diakses tanggal 21 Agustus 2017.

Musgrave, Richard A., \& Musgrave, Peggy. (2007). Perpajakan, Buku I. Jakarta : Diadit Media.

Soekanto, S. (2006). Pengantar Penelitian Hukum. Jakarta : UI Press.

Juwana, H. (2017). Problematika Hukum di Indonesia, Bahan Kuliah Aspek Hukum dalam Kebijakan Ekonomi, Magister Perencanaan dan Kebijakan Publik Universitas Indonesia.

\section{Peraturan Undang-undang}

Undang-undang Nomor 23 Tahun 2014 tentang Pemerintah Daerah

UU.No.25 tahun 2007 tentang Penanaman Modal Peraturan Pemerintah Nomor 45 Tahun 2008 tentang Pedoman Pemberian Insentif dan Pemberian Kemudahan Penanaman Modal di daerah

Peraturan Presiden Nomor 91 Tahun 2017 tentang Percepatan Pelaksanaan Berusaha Peraturan Daerah Kota Padang Nomor 3 Tahun 2012 tentang Penanaman Modal

Peraturan Daerah Kota Padang Nomor 11 Tahun 2009 tentang Pemberian Intensif dan Pemberian Kemudahan Penanaman Modal 


\section{J urnal, Prosiding dan Paper}

Tambunan, T. (2006). Iklim Investasi Di Indonesia : Masalah, Tantangan Dan Potensi, J urnal Bisnis \& Ekonomi Politik, Vol. 6 (No.3).

Prasetiyo, Agus., Pujiyono., \& Sa'adah, Nabitatus. (2016). Praktik Penyidikan Terhadap Wajib pajak Yang Melakukan Tindak Pidana di Bidang Perpajakan Di kantor Wilayah Direktorat Jenderal Pajak Jawa Tengah I, Diponegoro Law Journal, Vol. 5, (No. 3), pp.1-20.

Nirmalasari, Delia Saras., Juliani, Henny., \& Sa'adah, Nabitatus. (2016). Tinjauan Yuridis Terhadap Penyerapan Anggaran Daerah Kota Semarang Dikaitkan Dengan Diskresi Pejabat Pemerintah Kota Semarang. J urnal Diponegoro Law Review, Vol.5 (No.2), pp.1-20.

Dellisa A. Ridgway dan Mariya A. Thalib. (2003). Globalization and Development : Free Trade, Foreign Aid,Investment and The Rule of Law. California Western International Law J ournal, Volume 33.

Kurniawan, (2013). Pembentukan Produk Hukum dalam rangka Penyelenggaraan Pemerintahan. Kanun J urnal IImu Hukum, Vol.15 (No.3), pp.519-546.
Bintang, S. (2010). Otonomi Khusus Dalam Penanaman Modal Dan Permasalahan Hukum Yang Terkait : Studi Kasus Di Provinsi Aceh, Kanun J urnal IImu Hukum Vol.12 (No.2), pp.293-333.

Handayani, S. (2011). Upaya Pemerintah Sumatera Selatan Menarik Minat Investor Asing Dalam Penanaman Modal. Jurnal Dinamika Hukum, Vol.11 (No.1), pp.62-70. Yesi Hendriani Supartoyo , Jen Tatuh dan Recky H. E. Sendouw. (2013). The Economic Growth And TheRegional Characteristic : The case Of Indonesia. Buletin Ekonomi Moneter dan Perbankan ed.Juli, Penerbit Bank Indonesia.

Hazjimsum, Y. (2014). Model Demokrasi Dalam Pelayanan Publik, J urnal Dinamika Hukum Vol.14 (No.3), pp.445-457.

\section{Hasil Wawancara Narasumber}

Wawancara dengan Bapak Richardi sebagai Kabid Promosi dan Pengawasan Penanaman Modal DPMPTSP, tanggal 20 Desember 2017 